DOI: https://doi.org/10.18485/bells.2016.8.16

UDC: 821.21 .09

UDC: $305-055.2$

Dipannita Datta*

The Neotia University

Kolkata

India

\title{
TRADITION TRANSFORMATION AND POSTCOLONIAL FEMINISM IN INDIA
}

\begin{abstract}
Between 'tradition and transformation' there is a liminal space of transition with its different aspects of dependencies and interdependencies of power relations, and features that encompass the process of negotiation and opposition of cultures. In the context of Indian postcolonial condition, transition was an arduous one. Tradition was inflected by colonialism and the transformation that took place thereby bore a complex picture of cultural superiority of the colonizer and inferiority of the colonized, especially that of the colonized woman. Considering the vast trajectory of literature in India including the tradition of women's literature from different socio-cultural groups, this paper argues that it would be wrong to universalize homogeneity. It examines and identifies certain issues relating to the possibilities of women's literature in India, which otherwise would have remained unresolved at a macro level and addresses that rooted in Indian tradition, feminism in India has shown the route to an inclusive cultural transformation without generating exclusivity or a tendency towards separatism.
\end{abstract}

Keywords: Patriarchy, Tradition, Transition, Transformation, Indian literary studies, feminism.

E-mail address: dipannitadatta@gmail.com 


\section{Introduction}

Discrimination against women is a potent force of unevenness in the twentyfirst century across the world. To establish the dignity of human relationships across boundaries, feminist intervention and woman's rights activism have interrogated visible forms of ostracism and disenfranchisement influencing society but invisible forms continue in various ways in specific societies. Moreover, the growing menace of divisiveness in the world is seeing the faces of colonial-imperialism and influencing gender politics symptomatized by global dissatisfaction with intercultural ties. What measures plural feminism/feminism beyond boundaries can take to overcome the jarring challenges and generate an atmosphere of dialogue?

If unsettling to construe, I suggest that tensions and conflicts of gendered politics operative in a particular society demands flattening of differences and cannot be rejected both locally and globally. On the other hand, gendered politics is especially germane when the current emphasis is on 'woman's right is human right'. Although the above objectives operate on a seemingly different plane, I think the paths towards advancement demands perception of the impossibilities of 'monolithic operations' or external monolithic constructs about the differences that problematise a woman's identity. Moreover the internal differences cannot be overlooked. To make sense of the 'real' difficulty of moving towards a progressive knowledge, this paper will focus on debates pertaining to the distinctive nature of the women's question including woman's identity in Indian feminism.

Several feminist scholars and activists have argued that Indian feminism is unique because it is more practical than theoretical. ${ }^{1}$ Besides, Indian feminism, I suggest, significantly demonstrates a different experience in the sameness of feeling for the woman's struggle for freedom (mukti). The point I am trying to make is that Indian feminism does not ineludibly indicate or generate exclusivity, and a tendency towards separatism. As examples the analysis will examine the feminist interventions and textual representations of some woman authors of Bengal/India, namely, Toru

1 See, Madhu Kishwar, 'Why I Do Not Call Myself a Feminist', Manushi, 1991. No. 63-4, pp 38-40; Madhu Kishwar. 'A Horror of "Isms": Why I do not Call Myself a Feminist', in Maitrayee Chaudhuri (ed.), Feminism in India, New Delhi: Kali for Women and Women Unlimited. Also, for more discussions on Feminism and India, see Maitrayee Chaudhuri, (ed.), 2004, Feminism in India, New Delhi: Kali for Women and Women Unlimited. 
Dipannita Datta: Tradition Transformation and Postcolonial Feminism in India

Dutt (1856-1877), the Chatterjee-sisters, Santa Devi (1893-1984) and Sita Devi (1895-1974), and Ashapurna Devi (1909-1995).

\section{2. 'Feminism' - A Debated Term in India (a literary-historical analysis)}

First let me clarify why 'feminism' is a debated term in India, not to mention the other Asian or African countries once colonised. Feminism as a theoretical approach did not exist in India or for that matter in Asia or in any ex-colonies. The reason behind this, as discussed by several feminists in India (eg. Aparna Basu 1976, Madhu Kishwar 1991, Radha Kumar 1993, Leela Kasturi and Veena Mazumdar 1994, Meenakshi Mukherjee 1995 amongst others) ${ }^{2}$, is that feminism was not needed to be practiced exclusively. The fact that feminism as a separate theoretical apparatus was not essential in Indian society, does not signify that it is a "pure' ahistorical ideal". ${ }^{3}$ Rather, emptying India's history of all conflicts erases the cultural impositions on women, which were induced and accentuated by colonialism, and patriarchal needs simultaneously.

Moreover, as the colonial subordination impinged on the gendersexuality dynamics and on the daily life of women in the nineteenth and twentieth century Bengali society (within Indian), the tradition of patriarchy did not vanish with the onset of colonialism in India. Patriarchy as "a system of social structures and practices in which men dominate, oppress and exploit women", to use the words of Sylvia Walby, ${ }^{4}$ reasserted itself as well as went through changes during the colonial period and even after India gained its independence in 1947. In the Indian context, however, several scholars have argued that the nationalist patriarchs (who also fought for the independence of the country) and the facilitators of women's cause could not be directly opposed to each other. In this regard, I suggest, not only was the male identity to be asserted afresh, but also the female identity became significant and in need of transformation.

\footnotetext{
2 For more on Indian feminism as advocated by these authors, see, Dipannita Datta. Ashapurna Devi and Feminist Consciousness in Bengal. New Delhi: Oxford University Press, 2015.

3 Maitreyee Chaudhuri, 2004: xvii.

4 Sylvia Walby. Theorising Patriarchy. Oxford, London: Basil Black Well. 1990, 20.
} 
In fact, owing to varied class, caste, religion, ethnicity and language practices and the problematic interlocking of the historical conflicts between the coloniser and the colonised, the diversity in Indian culture and society contributed largely to the inclusive approach of feminism in India. In a multilayered socio-cultural milieu, it is only natural that there were varied feminisms emerging from different parts of the country, but during the era of colonial rule all were directed towards one goal and that was independence of the country. Therefore, in spite of the internal differences men and women were not divided at least during the struggle for independence. While the 'women's question' was not seperated from the concerns of the larger struggle (the anti-colonial struggle or the struggle for independence) because majority of both men and women believed that there was no need for an exclusive domain for feminism, interventions on women's problems continued both at individual level and at collective level both by men and women.

Feminists, like Radha Kumar, Joanna Liddle and Rama Joshi, insist that women in India were also supported by 'our men', who were leaders of the Indian National Congress, in their demands for suffrage, (unlike the 'suffragettes who had to struggle for the vote'). ${ }^{5}$ In this respect, Indian feminist's movement sharply differs from the suffregette movement to which much of western feminism owes its roots. Kumari Jayawardena known for her pioneering work on feminist movement in Asia in the nineteenth and early twentieth centuries defines feminism as '[...] embracing movements for equality within the current system and significant struggles that have attempted to change the system'. ${ }^{6}$ Indian feminists like Vina Mazumdar links the anti-imperial/ anti-colonial struggle of the national movement with awareness of women's issues as 'the independence of the country and of women has become so intertwined as to be identical'. ${ }^{7}$ In a similar vein,

5 Radha Kumar. The History of Doing: An Illustrated account of Movements for Women's Rights and Feminism in India, 1800-1990, New Delhi: Zubaan, 1993, 194-95; Joanna Liddle, and Rama Joshi. 'Gender and Imperialism in British India', Economic and Political Weekly, 1985, Vol. 20, No. 43, WS 72-WS 78.

6 Kumari Jayawardena. Feminism and Nationalism in the Third World, London: Zed Books, 1986, 2. Also see, Chaudhuri, 2004: xvi.

7 Vina Mazumdar. 'Whose Past, Whose History, Whose Tradition?: Indigenising Women's Study in India', Asian Journal of Women's Studies (AJWS), 2001, Vol. 7, No. 1, pp. 133-53 [135]. Also see in Maitreyee Chaudhuri, 2004: xxxi and in Dipannita Datta. Ashapurna Devi and Feminist Consciousness in Bengal. New Delhi: Oxford University Press, 2015, 23. 
it can be said that colonialism and the suppression of women's issues were intertwined. Women's progress especially after 1914 was stalled.

As Dagmar Engels argues, 'women's issues were avoided at this time thanks to Gandhi's deployment of women in the Independence struggle'. ${ }^{8}$ It must also be noted that in the nineteenth century the initiative of the social reformers, like, Iswarchandra Vidyasagar and Rammohun Roy prompted the legal initiatives to outlaw certain abuses (like sati and child marriage) and remove certain restrictions on women. Yet, in spite of their efforts to improve the conditions of women in India, Laws introduced by British administrators did not progress much; and there were reasons for that. The way the Personal Laws were constructed and with which the state arbitrated over women's legal rights contributed to an excessive scripturisation of Hinduism, which were never a religion of the Book. ${ }^{9}$ Till the point the British could demonstrate the liberalising influence of Western culture, Britain defended her right to rule with arguments about Western cultural superiority. Any claims regarding the advanced position of British women played an important part in the construction of this ideology. ${ }^{10}$ It is interesting to note here that cultural imperialism would soon take to political imperialism. The moral principle of female emancipation which had before 1914 been used to legitimate their rule was now eschewed for the sake of political stability. As observed by Liddle and Joshi, by 'maintaining women's subordination [the colonisers] could show that India was not yet fit for Independence'. ${ }^{11}$ The rapacious colonial civilising mission of the 'modern' or progressive over the traditional or the 'savages' with their non-modern cultures and traditions, was on.

The history of feminism in India, however, was not merely the story of how colonialism exercised power. It was also about the history of attempts by the colonised, both men and women, to acquire power. In the heydays of colonial rule, the advocates of colonisation equated women with colonies.

8 Liddle and Joshi 1985, 74; Dipannita Datta. 2015, 15.

9 Jasodhara Bagchi. (ed.), Indian Women: Myth and Reality, Hyderabad: Sangam Books. 1995: 3-8; Dipannita Datta. 2015, 15.

${ }^{10}$ See, Dagmar Engels 1983 and Liddle and Joshi 1985.

${ }^{11}$ Liddle and Joshi 74. The colonial government may have wished to free Indian women from male dominance, but they did not intend to do so by allowing them equal voting rights. It would indeed have been difficult for the British to agree to such a policy in India in 1919, since women in Britain were not granted the vote until 1928. See, Joanna Liddle and Rama Joshi 1985: 74. 
This separatist idea of the coloniser defines the gender-sexuality dynamics to a certain extent prevalent in British-India and also explains how the colonised challenged the system from within. The idea also facilitated the concept of the 'other'. The controversies surrounding the western feminist interpolation into the 'native women's question' and assessment of Indians as unfit for self-rule, were deeply criticised with furious rejoinders to Katherine Mayo's allegations on Mother India (1927) by 'our men', like, Mahatma Gandhi and Rabindranath Tagore, the two proponents of anticolonialism in India. ${ }^{12}$ They asserted their anti-colonial stance and calmly dismissed the book as another tired apology for the 'colonial civilizing mission'. ${ }^{13}$

Simultaneously, it be noted at this juncture that while different types of patriarchy - brahminical patriarchy, tribal patriarchy, dalit patriarchy etc., took their own stances to preserve the indigeneity of India, feminists too, although differed in terms of their religious and regional variations, asserted their rights including their right to work for the love of country. So, it is difficult to avoid being cautious of the colonising approach or dominant feminist's proprietorial attitude of universalising homogeneity and monolithic constructs about the differences that problematise identity. There cannot be any generalised assumption of Indian or by extension Asian women as 'passive victims' or 'passive recipients of the welfareenhancing help'. ${ }^{14}$ This is not to suggest that colonial establishments did not show any way to progress or towards enhancing living conditions of women, but that was directed towards proving their own superiority.

${ }^{12}$ Freedom' from the 'shackles of domesticity', and 'fearlessness', were the mottos of Gandhian mass mobilisation. Rabindranath took to women's education at different levels which would have practical benefit in day to day life. In brief, they showed the possibility that there can be an extension of the given' domain and that there was a mingling of male and female spaces.

${ }^{13}$ For further study, see Leela Gandhi "Postcolonialism and Feminism". Postcolonial Theory: A Critical Introduction. New Delhi. Oxford University Press, 1998.

${ }^{14}$ Amartya Sen 'Women and Men'. The Argumentative Indian, London: Penguin Books 2005, 222. Also see, Amos and Parmar in Chandra Talpade, Mohanty, 'Third World Women and the Politics of Feminism', Feminism Without Borders: Decolonising Theory Practicing Solidarity, Durham and London: Duke University Press, 2003, p. 77, N 14. Amos and Parmar and Mohanty have described the cultural stereotypes present in Euro-American feminists thought and have critiqued the Euro-American for universalizing homogeneity of the image of a passive Asian woman subject to oppressive practices within the Asian family with an emphasis on wanting to 'help' Asian women liberate themselves from their roles... 
In this complex scenario adapting the victorian duo - the 'private' and the 'public' - as a methodological approach would be risking simplification. A new challenge surfaced for the women of Bengal: how the spaces of Indian tradition and modernity should be negotiated? Partha Chatterjee, a postcolonial historian of repute observed, "after all, 'ours is the modernity of the once-colonised'. The same historical process that has taught us the value of modernity has also made us the victims of modernity. Our attitude to modernity, therefore, cannot but be deeply ambiguous. It is superfluous to call this an imagined past, ... [And] 'Those days' for us are not a part of an historical past; we construct it only to mark the difference posed by the present". ${ }^{15}$ In this regard, the crisis of imitativeness within anticolonial nationalism assumed existential proportions for its problem was not simply to produce, as Chatterjee puts it, 'a different discourse, yet one that is dominated by another'. ${ }^{16}$ That is, although colonization made it imperative to introduce an absolute distinction between the 'Self' and the 'Other', the emergent nationalism made it equally imperative to stake out claims to sole representational authority over the self. ${ }^{17}$ In this very act of defining the 'other', which defined the 'self' in each case with the essence of the other, home found a new meaning. The women of India were ensured freedom, but, that was highly synonymous with the freedom of maintaining the traditional 'spiritual' (feminine) ethos within the defined 'inner' space - the 'ghar'/the home.

This anti-colonial social space, thus introduced as one aspect of the nationalist project by our men, was to protect the 'the inner spiritual self, our true identity' and our women - its representation from the 'encroachments by the coloniser... in the inner sanctum'. ${ }^{18}$ The 'outer' space of the 'material' interests, the 'bahir'/the world, remained 'typically the domain of the male' 'where practical considerations reign[ed] supreme' and 'where the battle would be waged for national independence'. ${ }^{19}$ We get two pictures from this reading. One, for instance, a clear-cut 'separation of

\footnotetext{
${ }^{15}$ Partha Chatterjee, 'Our Modernity'. Sephis and Codesria, Rotterdam \& Dakar, 1997.

${ }^{16}$ Partha Chatterjee, Nationalist Thought and the Colonial World: A Derivative Discourse, London: Zed Books, 1986, 42.

17 See, Dipannita Datta. 2015 'Intoduction'.

${ }^{18}$ See Partha Chatterjee. 'The Nationalist Resolution of the Women's Question', in Kumkum Sangari and Sudesh Vaid (eds), Recasting Women: Essays in Colonial History, New Delhi: Kali for Women, 1989: 238-9. Also see, Dipannita Datta. 2015, 21.

${ }^{19}$ Partha Chatterjee 1989, 238-239.
} 
the social space into ghar and bahir' ${ }^{20}$ both exclusive of the other, and the second, a gendered division - where the category 'women' were labelled as repositories of the 'home' and 'men' were subsumed to face the treacherous terrain - the 'world'.

In brief, the responsibility of retaining the traditional culture of the nation, which was defined as nurturing the spiritual quality of national culture, was on women and home was seen as 'nation' in its embryonic form. The reintroduction of the traditional culture that was posited by the nationalists to maintain the 'cultural identity' and signify the 'difference' from the rulers led to several restrictions on women's participation in the public sphere or the area outside the demarcated area of protection. ${ }^{21}$ This mode of reintroducing traditional culture, in which recasting of women took in various forms, created unease amongst generations of feminists and continues till date. Maitreyee Chaudhuri, a contemporary feminist, remarked, '[D]during the colonial period the negotiation led to a trend of essentialising 'Indian culture' and a construction of an image of recasted Indian womanhood as an epitome of that culture...22

With time, of course, there was a shift in the functional aspects of the social architecture, but to what extent did it change? How could women imagine of their freedom in such a social architecture thus constructed by the 'nationalist patriarchy'? Toru Dutt, the Chatterjee-sisters: Santa Devi and Sita Devi, and Ashapurna Devi continued to write in an arduous phase of transition and in an atmosphere of complexities and contentions and offered a rich account of how, through the combined process of reconciliation with and resistance to patriarchal ideology women were able to initiate changes and challenge the system from 'within'. But, how one could read the 'personal' and the 'political'? The following section, drawing upon Indias rich political and intellectual history of women's writings will address a set of inter-related themes: (1) to what extent has colonialism and its binary nationalism in India hindered and improved critical thinking of the authors Toru, the Chatterjee-sisters and Ashapurna Devi. (2) It will focus on how women forged out an identity by aligning themselves with the prevailing structure of the renewed patriarchy, (3) How far each of these authors negotiated the political concerns of the time?

\footnotetext{
${ }^{20}$ Ibid., 238.

${ }^{21}$ Jasodhara Bagchi. 1995, 4.

${ }^{22}$ Maitreyee Chaudhuri. 2004, xix.
} 
Dipannita Datta: Tradition Transformation and Postcolonial Feminism in India

\section{Feminist Interventions and Textual Representations}

\subsection{Toru Dutt}

Among the women writers under discussion, Toru Dutt chronologically comes first. It is not simply for this reason that I start this part of the analysis with her. Dutt in her prose writings (eg., Bianca) and especially in the poems resolved the awful contradiction between the world which she wanted to write about and the language English she wrote in. Toru Dutt, was born in Bengal, and she was the first significant Indian woman poet and writer in English who did not surrender an anti-colonial intellectual position. She, rather, gave her anti-colonialism a significantly broader base by traversing the complex terrain of oppression and rebellion within and beyond the calculated spatial strategies. Particularly pertinent was her conviction that the colonial situation was used creatively.

Toru (as she was commonly called) was an outsider in both Indian and British society: by her gender by her race and colonial status in British culture, and in Indian culture by her Christianity and English education. This experience of separation/ displacement became more intense as she struggled to make the world her home. The horizon of difference, which I would call the two-way traffic, did not seem to meet. Toru was educated in France and Cambridge. She returned to Bengal to write most of her poems. Yet, her anxiety, even if she was writing from her place of 'origin', seemed impossible to evade. Toru did not suffer a literal geographical displacement but the imposed gap (which resulted because she was a Christian and was writing in English in an 'invaded colony' or in the language of the colonisers and especially when the anti colonial movement had already started in India) denied her the shelter-the rationally ordained life of continuity that the home ostensibly offers. The English too did not offer her a secured place because she was not writing from the 'original' place of that literature.

Toru did not submit to the challenges of the time, and resisted cultural norms of an emergent nationalism which promoted Bengali as a full-fledged literary language from the last quarter of the $19^{\text {th }}$ century. For her, the very idea of national language (whether English or Bengali) itself was exclusionary. This raised questions about her knowledge of her mother tongue and her love for Bengal and India. Toru wished for "boyish freedom", which she described in her poem 'Savitri' (a poem re-written 
from the puranas) and did not submit to the 'new' invisibility of the girl's work, which located a girl/woman primarily in the domestic sphere. She, rather, recognised and deplored the fact that the meeting of cultures had come largely on the back of colonial exploitation and imperial conquest and wanted to move beyond the static and oppositional view of civilisations, stressing the limitless potential for everyone-the coloniser and colonised alike-to realise a new, more consummate, identity.

In her pain and deprivation surfacing as colonial ennui, she wrote to her English friend Mary Martin: 'The free air of Europe and the free life there are things not to be had here [...]. We cannot stir out from our garden without being stared at or having a sunstroke'. ${ }^{23}$ In another letter Toru writes, "it is considered "infra dig", unladylike, immodest, to walk in the street on foot' ${ }^{24}$. These and many other evidences from her letters confirm that it was not only the religious conviction aspect but also the question of family respectability and/or status that exiled Toru from the prevailing society.

Until recently, in the late 1990s, Toru Dutt was relegated to the critical outskirts because scholars were unsure how to engage productively with her work. A new generation of postcolonial feminists and transnational scholars, like Meenakshi Mukherjee, Chandani Lokuge and Kalpana Sharma, have brought about her critical rediscovery, thus helping the readers to develop critical understanding of Toru Dutt's work. These scholars have proposed several important potential contexts for her work - those of Toru as colonial conspirator, as an Indian nationalist, and as occupant of the free-floating in-between space but fails to consider her impressive agency as a writer-an agency that enabled her to strategically emphasise and minimise certain dimensions of her subjectivity for specific political, religious, or social purpose. While focusing primarily on the recent critical positioning of Toru, I analyse Toru's ability to privilege those aspects of her complex subjectivity and argue that if recent reclamation works are to be productive, the task of analysing her poetry needs to be approached both as an aesthetic and as a political.

${ }^{23}$ K.R. Srinivasa Iyengar, Indian Writing in English, New Delhi: Sterling, 1983, p. 60. Dipannita Datta. 'Nationalism, Anti-Colonialism and Universalism in lmperial lndia: 'The Poetry of Toru Dutt'. Understanding Britain Reader 1. London: 2012, pp. 32-42 [35].

${ }^{24}$ Chandani Lokuge, Toru Dutt: Collected Prose and Poetry, New Delhi: Oxford University Press, 2006, p. 317. Also see, Dipannita Datta 2012. 
The Sonnet-Baugmaree, ${ }^{25}$ which is 'an original enquiry into the nature of personal and colonial identity', ${ }^{26}$ is one poem in which such intricate formations emerge. Toru's 'hybrid' subjectivity (for example, and as the poem reflects) not only separated her from the nexus of the many determining ideologies like nationalism, imperialism, gender binarism and racism, but also it opened ways to the rich complexity of the interactions between and among those once seemingly unified constructs. The blending in herself of the complex subjectivity was a deliberate strategy to resist the violence of social injustice, which I think in turn enabled her to stitch together the different identities and disparate fragments of the "sharp contrasts of all colours" - the key line of the Sonnet - 'Baugmaree'. This conscious effort to overcome the boundary, both ideological and geographical, proves that young Toru had remarkable ability to discern the power of poetic language to resist the hegemonic culture of the coloniser quite instinctively.

Again, Toru was reminded of the brutal and random violence exerted against Indians by the British, and she returned to the subject in letters to Mary Martin, proving its tenacious hold over her. Sonnet-Baugmaree demonstrates that Toru was aware of India's colonial status, her own subjected position and Britain's imperial domination, and that the trumpet's sound could reach anywhere, even inside the private recesses of an Indian's garden. The poem also exemplifies Toru's aesthetic determination to destabilise the West's attempts to figure Britain's claims of legitimate colonial occupation.

The Sonnet- 'The Lotus' is another forceful articulation of Toru Dutt's fertile imagination, her precocious craftsmanship and of the young poet's ability to discern the power of poetic language to achieve her particular political end. Simultaneously, 'The Lotus' can also be referred to as a poem that subverts many of the binaries like male/female, public/private, West/ East etc. that the patriarchal ideology left essentially intact.

Furthermore, the lotus has been a persistent motif in ancient Indian poetry and mythology as an emblem of peace and tranquility. The serenity and purity that the lotus is associated with suggests hope and harmony for the nation; and Toru gracefully established the lotus as the unrivalled queen of flowers signifying 'seductively feminine Empire striking at the

\footnotetext{
${ }^{25}$ First published in Ancient Ballads and Legends of Hindustan, London: Kegan Paul, 1882 (introduction by Edmund Gosse).

${ }^{26}$ Rosinka Chaudhuri, Gentlemen Poets in Colonial Bengal, Calcutta: Seagull, 2002, p. 4.
} 
Centre'. ${ }^{27}$ This spontaneous, innovative and bold attempt of Toru certainly demonstrates 'The Lotus' as a developed rendition of complex dimension, both cultural and political, heralding "the beginning of cultural fusion without surrendering indigenous identity'. ${ }^{28}$

[At this point we must remember that 1857 was the year of Sepoy Mutiny and which was the first mass uprise against the colonial rule]. Considering the all-round unrest that the nation was witnessing, Toru skillfully employed and blended international icons of mythic power to emphasise the superiority of the national icon through the cultural fusion effected through 'harmonious assimilation' of the 'Occidental' or Western red rose and white lily and the innate chemistry that empowers the lotus - the national flower of India. By engaging with the Western literary symbols and traditions - like the red rose, (a symbol of love, beauty and respect) and the white lily (a representation of purity and majesty), Toru projects lotus as the 'undisputed queen' by showing that the flower might be 'other' and strange, it is not separate from the lily and rose - instead, it is an amalgamation of their two colours.

Simultaneously, by emphasising on Flora's political power and stressing the hybrid nature of Lotus, Toru envisions gender equality and autonomy for the 'East' without separateness from the 'West'. In this respect 'The Lotus' can be assessed as a profoundly political poem. Toru Dutt has interspersed both the poems with patriotic flavour, or for that matter patriotic responsibility, as she transits between cultures, translating one into the other. So we can say that it was in the merging of the 'sharp contrast of all colours' that Toru found her strategic self and defined the other.

\subsection{Santa Devi and Sita Devi}

The Chatterjee sisters known as Santa Devi and Sita Devi hailed from the Brahmo faction of Hindu liberal upper middle class family in Bengal. A point to be noted here is that during the pre-independence days, even if the roles played by women (and men) from varied strata of the Bengali society were different, a major concern of all were directed towards one goal; and that was the independence of the country.

\footnotetext{
${ }^{27}$ Chandani Lokuge 2012 xliv.

${ }^{28}$ Sanjukta Dasgupta. Indian Literature. Sahitya Akademi Journal. 1998, No. 187 [SepOct], 208. Also see, Chandani Lokuge 2012 xliv.
} 
In the early twentieth century colonial Bengal strands of western influence were witnessed in male writers, and the cultivation of western thoughts was but rare amongst the women writers of Bengal. It is in this interesting literary intersection of traditional Bengali writing and westerninfluenced literary writings in Bengali that the works of Santa Devi and Sita Devi were both found and lost. Their works were lost not because their writing was lacking in quality, but because a more complicated process was at work. Meenakshi Mukherjee, a postcolonial critique of creative literatures, argues, 'Literary texts get canonized in different and invidious ways...'29 Not all categories of writing at a given time get equal attention and enter into literary circulation. Santa Devi's and Sita Devi's writings became prominent over a short period of time and their books soon became unavailable to readers and gradually died out. One reason of the decline was that the sisters were "Brahmos"-a faction of Bengali society averse to superstitious beliefs. They were quickly stamped as "militant" writers by the traditionalists (I use this word in an uncomplicated way) and their books went out of circulation, in spite of their richness of thought and interesting way of writing. Now, very few of their books are available even in the National Library.

Two trends of women's writings were distinctly visible in this period of literary history. The first trend included those individuals who highlighted the problems of women and yet kept themselves restricted within the then existing social norms. These writers stood against the attack of western education and culture on Hindu ways of life by supporting and singing the praise of the ideals and legitimacy of traditional Hindu religion. Anurupa Devi (1882-1958) and Nirupama Devi (1883-1951), the two prominent Bengali women writers are particularly mentionable among the writers of this group. The other trend of writing was constant adaptation of western thoughts without overruling the traditional norms. Santa Devi and Sita Devi belonged to this progressive stream of writers. Their literary creations reflected the coordination of their inlaid thoughts with western feminism, opening a new area of thinking and a new outlook to the women of Bengal. ${ }^{30}$ The main focus of their writings was the constant analysis of the intricate mentality and change in emotional faculty of the females of

\footnotetext{
${ }^{29}$ Meenakshi Mukherjee. Perishable Empire. New Delhi: Oxford University Press, 2003, 13

${ }^{30}$ I have compared Santa Devi's and Sita Devi's work with G Eliot's, but here it is not within the scope of discussion. For further study see, Dipannita Datta. A Caged Freedom, Kolkata: Writers Workshop, 2001.
} 
the society inundated by the diverse current of western education. They placed woman as a conscious and enlightened companion of man in the complicated and strifeful field of life's struggles.

Until 1936, when public opinion was roused and women's issues were taken up, the whole subject of women's education was 'riddled with contradictions'. Education, which was taken up as a nationalist project, not only promised freedom and equality but it was projected as a program that would shape the child for responsible citizenship. As far as Santa Devi's and Sita Devi's writings are concerned, same sentiments echoed regarding education and women's role in society and there were little that distinguished their work from the male writings of that time. Yet, their writings had a distinctive flavour of their own. They looked at life and society with a woman's own feeling and outlook. It ushered in a whole new range of possibility that was not thought of in early twentieth century Bengal. In the case of Santa-Sita, as also noticed in the case of Toru Dutt, we see there were several contradictions that the sisters had to contend with and that the question of religious conviction was not the only aspect that displaced the sisters from the prevailing society, albeit reasons were different. Right from their early phase of writing, the sisters expressed their doubt on developing characteristics according to gender analysis and thereby shaped a new approach to society and ethics. They believed that the very notion of polarization was derogatory to any social development and daringly introduced coeducation schools and colleges (where girls and boys could mix freely) in their first novel Udyanlata (Garden Creepers, both 1919).

Points to be noted here are: (i) Both sisters voiced their protests against the system (both patriarchal and imperial) but not against the males. (ii) Both of them insisted on education in their agenda towards social development and maintained that the basic elements, like fear and guilt, that have the potential to kill self-determination-were to be erased first from the psyche of both men and women. (iii) Both, although brought up in a liberal Brahmo atmosphere, were not against the Hindu religion. Both the sisters celebrated all the Hindu festivals, which their father Ramananda Chattopadhyay (the renowned political journalist in BritishIndia) also appreciated and promoted.

In her own life, Santa Devi unlike her sister Sita Devi did not participate in the anti-colonial movements, but stood firmly against the British policy of 'divide and rule'. The policy that not only divided the Indian nation 
into a geographical cage but also divided the Indian people amongst themselves in terms of religion. The imposition of the Hindu marriage bill by the British administration is a case in point. Santa Devi declined to sign a legal document saying, "I am not a Hindu", during her marriage with the Indian historian Kalidas Nag (whose identity as a Hindu was only derived from his identity as an Indian, or, whose identity as a Hindu was only second to his identity as an Indian). ${ }^{31}$ Simultaneously, both the sisters consciously pursued to portray a model non-Hindu tradition in their novels, which were also systematically integrated with the tradition. In this sense they contributed significantly to widening the aesthetic and cultural atmosphere of the time. Their undogmatic defence of ideas concerning allegiance to human ties that resists separatism and promotes an exchange of views and culture (both of which are vital aspects of education) are reflected in Udyanlata.

This novel was a joint venture of Santa Devi and Sita Devi and they wrote it in the name of Sanjukta Devi (Sanjukta meaning being together). For both the sisters, it was unacceptable to have a communication, be it in love or in creative aspirations, restricted by artificial boundariesgeopolitical or ideological. Mukti, the female protagonist of the novel exemplifies this search, and also manifests the search of a "new woman" (as posited by Partha Chatterjee 1989). The novel additionally reflects the thinking of the world poet and philosopher Rabindranath Tagore who intrepidly proclaimed 'no education becomes a vital part of ourselves' until seen as a common, human heritage. ${ }^{32}$ Thus Mukti, the name which bears its symbolic significance in the text because it means freedom in Bengali, was invented to read Marie Corelli (pseudonym of Mary Mackay 1855-1924) and George Eliot (pseudonym of Mary Ann Evans 1819-1880), proposing exchange of ideas and artistic achievements were important for changes to take place in a society.

This idea of creative freedom, suggesting women' uplift, was considered absurd within the normative framework of colonial Bengal. The late nineteenth and early twentieth century Bengal was marked by internal repression and colonialism in India, and women were under double subjugation. On the other hand, the concept of woman as the "weaker sex" which was very much prevalent in England, especially the Victorian

${ }^{31}$ See Dipannita Datta, 2001.

${ }^{32}$ Rabindranath Tagore. The Oxford Tagore Translations. New Delhi: Oxford University Press, 2001, 188. 
England as portrayed in the novels of Corelli and Eliot influenced the literary scenario in Bengal/India. In Udyanlata, the authors initiated the concept of "weaker sex" in a new way and introduced the vibrant images of girls and boys going to school.

The novel was indeed an intentional leap from the traditional norms. It was also challenging the new standards introduced by the British administration so as to make the girl (the so called "weaker sex") conscious of a new sphere of life that was chosen to be a male child's priority and rarely a necessity for a female child. Thereby, they implanted a new stream of thinking and brickwork for the girls who were looking for ways to liberate themselves from the strict conventional and dominant norms operative in society. The novel represents full of lively moments with a new generation of educated and career-oriented girls and boys having an equal share of experience and normal exchange of thought and activity that was not contemplated by any other novelist of their time. But, this 'new' freedom, according to Partha Chatterjee, has been accorded to women by the 'new nationalist patriarchy' that 'had to be normalised' enabling women to speak for themselves'. ${ }^{33}$

Mukti is undoubtedly an admirable woman endowed with all feminine qualities; she is also a fiercely independent spirit, confident of her own choices and ability to think them through for herself, a woman no less capable of sound reasoning and decision making, often more so, than her male counterparts such as Dhiren. Neither should the sisters' appreciation of women-as-mothers be understood as part-and-parcel of the then dominant nationalist project in which 'the loving relationship between mother and son' came to supplant the fractured ideology of Hindu conjugality based on a defensive valorisation of child marriage. ${ }^{34}$ In contrast to the new anti-colonial nationalist scenario in which the woman is deified as Mother Goddess and seen to represent the Motherland, only to be subordinated in real life, Mukti is very much a flesh-and-blood woman, with her own distinctive voice and agency rooted in her loving capabilities but greatly enriched by her key role as a dispenser of wisdom, a torchbearer for the younger generation and initiator of action.

\footnotetext{
${ }^{33}$ Partha Chatterjee, The Nation and Its Fragments: Colonial and Postcolonial Histories, Princeton: Princeton University Press, 1993, 133.

${ }^{34}$ For a theoretical approach to child marriage, see, Tanika Sarkar. Hindu Wife, Hindu Nation: Community, Religion, and Cultural Nationalism, Delhi: Permanent Black, 2001.
} 
Yet, it is the women characters (like, Mokhshada, Khuku, Hemnalini, Kamini, and Aparna) in this novel and not only Mukti who are the movers and shakers. They are true figures of revolution, able to stand up to oppressive conventions and bear public consequences. If this domain belongs to Mukti, Mokshada on the other hand constitutes the literary representations of women who have internalized patriarchal beliefs and serve to reproduce them, thus disproving any necessarily direct, or natural, link that might suggest to exist between women and radicalism, or women and loving kindness. These traits in the novel cut across gender boundaries, even as they are foregrounded through a number of leading female characters.

Furthermore, with regards to "the novelists with their "realist" ambitions, the problem of sculpting a new woman took an added dimension. Fiction had to negotiate the uneasy fit between the "myriad microscopic assumptions" that went into creating the "reality-effect" of the nineteenthcentury European novel and the everyday worlds in Calcutta that was mediated by a thousand other forms and ideologies that the novelists and their readers lived in. It was not enough for these writers that the woman should only be an efficient homemaker and a supportive companion. They needed a new woman molded into such proportions that the hero could plausibly fall in love with her'. ${ }^{35}$ In other words, 'in the writings of Santa Devi and Sita Devi we get [insights into] how women wrestled with these projects, infusing into them totally illegitimate extensions and indecorous deviations'. ${ }^{36}$

Having spoken briefly about Santa Devi and Sita Devi, their writing skill, balanced practical outlook and their distinct ways of conceptualizing feminism beyond boundaries, we will now turn to Ashapurna Devi and her insights into creative feminism.

\subsection{Ashapurna Devi}

Unlike Toru Dutt or Santa Devi and Sita Devi, Ashapurna Devi was homebound and a devout Hindu woman. The authenticity of Ashapurna's fictional representation is beyond question for she is one woman-writer of

\footnotetext{
${ }^{35}$ Dipannita Datta, 'Womanhood, a Myth and Reality', South Asian Review. 2004, Vol. 25, No. 1, pp. 327-44 [330].

36 Ibid.
} 
twentieth century Bengal who was not readily influenced by the English language or literature. She was unacquainted with formal or even informal English education. Yet, Ashapurna's narratives articulated a new way of portraying women in creative literature: a way that linked the question of freedom and justice to the identity of the woman as an individual. This is the hallmark of Ashapurna's narratives. Yet, her seminal attempt to analyse women's situation with intellectual sophistication is one of the least read works in current feminist critical enterprise. The reading in this section aspires to show Ashapurna's unique quality of offering a feminist critique of the male ordering by interrogating the situation in the public front.

Ashapurna clearly maintained in her wide ranging works, from poetry to prose writings and also in her public lectures/essays, ${ }^{37}$ that despite various contradictions and pressures of various ideologies in relation to their material circumstances, a way to an independent representation and expression of identities may be initiated through the solidarity of the discriminated. I will read a small portion from Ashapurna's comment on the cultural marginalisation of women and on ways to overcome oppression operative in society as indicated in her 1995 lecture/essay "India woman: Myth and Reality".

Women need a special kind of self-sufficiency; [this] can come only with the consolidation of female power. In our society, women often stand in the way of other women's development. This is an inescapable truth... [Any] agitation around the term, woman's emancipation, will not emancipate women. What is needed is power... the power of sacrifice and detachment, the power to liberate oneself from the narrow confines of selfinterest, the strength to tear apart that veil of false consciousness and to stand out in the splendour of one's dignity.... It is important to remember that the struggle is against injustice and inequality, not against the male sex. If we have to proceed towards a better society it will not do for the two sexes to behave as if we were perpetually on a battleground.... Equal rights can be ensured only when men and women have attained the same level of consciousness... ${ }^{38}$

${ }^{37}$ See, Dipannita Datta. Ashapurna Devi and Feminist Consciousness in Bengal. New Delhi: Oxford University Press, 2015.

38 This essay 'Indian Women Myth and Reality' is a 1989 lecture of Ashapurna at Jadavpur University. It was published in Jasodhara Bagchi. (ed.), Indian Women: Myth and Reality, Hyderabad: Sangam Books.1995. See Ashapurna Devi. 1995:22-23. I have used this essay for its unique cultural commentary in the light of post-feminist thought, suggesting 
Such a trenchant understanding of the man-woman relationship is indeed a modern critique on certain gendered assumptions prevalent in society. For Ashapurna there was nothing wrong in retaining the dignity of traditional ethos and preserving the spirituality of national culture; yet, with remarkable authority she attended to the complexities regarding gender-sexuality dynamics operational in society and probed into the conventional understanding about women's struggle against injustice and inequality. Ashapurna's suggestion towards imparting a sense of solidarity as quoted above and which is also evident in many of her texts, invested Indian feminism with a renewed/transformed dimension of a balanced practical feminism, where human values ruled supreme, with perfect awareness of the oppression that women experienced because they were rendered powerless. ${ }^{39}$ The self-sufficiency that Ashapurna calls for is, thus, not only about reclaiming an agency for the self denying the other (i.e separating woman from men as social groups or Indian from non-Indian), but also a sufficiency of the self that will begin a resistance to different forms of domination in terms of both needs and rights, with emphasis on women's rights.

Adopting an optimistic view of what Ashapurna says, the analysis may seem to become complicit with the 'silencing' projects of patriarchy and imperialism. Ashapurna is not willing to forget the past. In her last novel (The Story of an Antahpur of Old Kolkata 1995) she returns to the days of the antahpur (when women lived in a space of their own, though that was a secluded domain). The novel not only marks the difference posed by the present but also it records her deep concern about the silent side of history. She writes:

Life moves on without a pause. Times are also changing. Along with that, even the views of life undergo a change ... but the past can never be erased from memory. Therefore, I continued writing about life.... ${ }^{40}$

Ashapurna's feminism gave directions to analyse the politics of the ongoing everyday subordination of women - the subordination that is related to other social formations as well. See, Dipannita Datta. Ashapurna Devi and Feminist Consciousness in Bengal. New Delhi: Oxford University Press, 2015, 23.

${ }^{39}$ For further studies on Ashapurna, see, Dipannita Datta 2015.

${ }^{40}$ Ashapurna Devi 1988 in conversation with Partha Chatterjee. See, in Dipannita Datta 2015. 
For Ashapurna to construct the future, 'those days' of colonial rule could not be a historical past. Rather, she was unable to underestimate 'the psychologically tenacious hold of the colonial past on the post-colonial present'. ${ }^{41}$ With such an understanding of the linear progression of time where 'differences' and 'borrowings' become a complicated process, Ashapurna opens up the debate on the place of gender in a renewed way in which we will see that the relationships between man-woman, insideoutside, West-nonwest cannot be directly oppositional to each other.

By way of responding to the silenced contours of the position of women in colonial India, Ashapurna observed in her preface to the novel Pratham Pratisruti, (which bagged the prestigious national Jnanpith award in 1977, translated as The First Promise)

$\mathrm{H}[\mathrm{h}]$ istory has invariably overlooked the dynamics of the domestic world. That domain has always been neglected. This book is about an unknown woman who was among those who carved out the etchings of a promise from within those ignored interior spaces of Bengal. ${ }^{42}$

Ashapurna's emphasis here is on the subdued/muted position of women where the acknowledgement of their experiences was concealed from the histories of colonial society. To grasp the question of 'becoming' as articulated by Ashapurna, we must consider the 'problematic' interlocking of historical conflicts, which she believed triggered the process of marginalising women and subverting their voices. (We have already discussed the 'problematic' interlocking and will not go into details here). What needs to be considered here is, Ashapurna continued to write in that atmosphere of complexities and contentions and offered a rich account of how, through the combined process of reconciliation with and resistance to patriarchal ideology, women were able to initiate changes and challenge the system from 'within'. She said, India's history was not a history of 'begging' or 'pleading' (Subarnalata). India has its own culture and women have

${ }^{41}$ Leela Gandhi. Postcolonial Theory: A Critical Introduction, New Delhi: Oxford University Press, 1998, 6.

${ }^{42}$ Pratham Pratisruti in Bengali was published in Kolkata: Mitra and Ghosh1964. The Translation in English-The First Promise - was done by Indira Chowdhury and published in New Delhi: Orient Longman, 2004. The translations used here are from Chowdhury. For a discussion on Ashapurna's feminist insights, see, Dipannita Datta 2015. 
Dipannita Datta: Tradition Transformation and Postcolonial Feminism in India

proved their intellectual acumen and their might in anti-colonial struggles. Indian women's revenge, at least during her time, was not on the male sex, but, against the system of injustice that ruled over class, caste and gender. The protagonist Satyabati's (First Promise) appeal for justice from the British police is a good example. 'Satya was in full flow' and said-

Just tell me why you've opened your courts of justice? ... There are heaps of sins that have collected over centuries. If you can rid us of those, only then would I say that you deserve to be lawmakers. Why have you taken on the guise of ruler in another's land? Why can't you just huddle into your ships and leave?'43

It is quite clear from the above assertion of Satya, or Satyabati - the eternal truth seeker, that she rages on about inadequate social measures. Ashapurna through Satyabati lifts the veil of the prevalent double standards in Bengali society, in pre-independent India and constructs women's demands around women's domestic, beyond the domestic and issues regarding domestic and against social oppression. But she was reminded of her misplaced hope on the colonial masters. Master Bhabotosh Biswas, Satyabati's and her husband Nabakumar's English teacher, made Satyabati aware of the need for developing self responsibility in building up a nation and her 'naïve faith in colonial justice and reform'. Bhabotosh Biswas, commenting on Satyabati's demand for justice from the colonial masters and her hope that the British laws would remove the social ills, remarked, 'that's a task for us'. ${ }^{44}$ From his slanting remark we can draw that Ashapurna makes her readers conscious about the fact that through the legislation of pro-woman laws the colonial state might have proved its administrative pragmatism, but as far as implementations and social transformations were concerned the work had to commence from 'within'. Yet, it is through the same master that the congratulatory response of the officer to Satyabati's courage is conveyed. Thus, without rejecting the hope on the colonial masters Ashapurna emphasised that it was the responsibility of the nationalists to retain the identity of the home-India and strengthen women's position from the dominant idea of the Indian woman as an 'oppressed subject'.

A space was created for women by a woman. Satyabati showed the possibility of a flicker of light at the end of the tunnel. This was possible for Satyabati partially because her father Ramkali would patiently listen

${ }^{43}$ The First Promise 484.

${ }^{44}$ Ibid. 485. 
to his daughter's observations and 'reflect on the ways in which atrocities were masqueraded as social custom and traditional practice'. ${ }^{45}$ Her father acknowledged Satya's unflinching approach to truth, but truth seeking formed the core of her character.

Satyabati like a true Indian woman maintained the emotional needs of a family life. She attended to the daily grinds of household matters meticulously and at last took to her 'own self into consideration' and became self sufficient at the same time. ${ }^{46}$ For thirty years of her married life Satya provided true care to the family members. She did not mind calling a 'Sahib' (non-Indian/Western) doctor to treat her ailing husband Nabakumar, despite the obvious ridicule she endured. She was also extremely alert about the need for education and thus she would not allow her daughter Subarnalata to remain uneducated. At the same time she refused to expose her children, including her sons to the extravagant life style of the 'wealthy' Calcuttans. ${ }^{47}$ She proved that by attending the daily grinds of household matters one could earn a keep and have a space of her own through sheer motivation. Satyabati, after moving to Calcutta took advantage of living in a nuclear family and taught adult women. Thereby, she showed the possibility that there can be an extension of the 'given' domain. But to retain that possibility, education should be promoted which has the potential to extend the boundary.

In Pratham Pratisruti (The First Promise) what Ashapurna Devi reminds us is that the "unknown" girl Satyabati who was given away in marriage at the age of eight to maintain the social norms were kept under strict surveillance of Brahmanical regulations. Yet, with a 'nose-ring dangling, heavy anklets round her feet' Satyabati continued the struggle for years at every step, battling against family control, mental violence of the kulin polygamy and social prejudices, to build the 'road on which the Bakuls and Paruls (the third generation women, i.e., Satyabati's granddaughters) are striding ahead'. ${ }^{48}$ She was not aware that she was making history yet the path was laid. It is worth noticing that these women, as Ashapurna claimsour 'mothers, grandmothers and great-grandmothers' - were lonely but

\footnotetext{
45 Ibid. xix.

${ }^{46}$ Ibid. 531.

${ }^{47}$ For eg., Ibid. 335.

${ }^{48}$ See, Dipannita Datta 2015, 25.
} 
not alone. ${ }^{49}$ It was a collective effort of building the roads and the ledge to move forward towards the mission. But such struggles do not find a place in the pages of history.

Satyabati's last letter to her daughter Subarnalata is another fine example of the dynamism that Indian women were endowed with and the patience with which such women answered themselves 'staking their claim where they [were] not allowed to tread'. ${ }^{50}$ I quote small portions from her letter. Satyabati writes,

$[\mathrm{H}]$ having analysed human behaviour time and again, I know now that it is easy enough to judge others harshly. Those who appear to do wrong, or what in others eyes might constitute a crime, do not always act with a deliberate intent to harm. Most acts out of ignorance are simply because they are misled. However, when such ignorance clashes with the saving of a young and innocent life, it is not easy to maintain calm... What is needed is patience. No task can be completed unless one is willing to move with care and with endless patience... I started a school for girls soon after my arrival here [in Varanasi]... When I first started, I had to beg people to send their girls. Now a lot of people bring their daughters voluntarily. The need to educate women has begun to be felt by many. ${ }^{51}$

Thus, from Ashapurna's perspective it was not right to lay blame on all men or on all those we think are unjust to women. What was needed was a change in the process of upbringing and socialisation. For her there was no question of revenge as far as a man-woman relationship was concerned. The primary effort should be to overcome the weakness of ignorance, which is the real enemy to the progress of society. When God created the opposite sexes, 'in His eyes they were not different; and certainly, one was not created just to serve the other'. Women like Satyabati and Subarnalata had clear perception of their marginalisation. Yet, they never dreamt of a world where men were treated as their enemy. 'In time, men will learn

\footnotetext{
49 Ibid.

50 The novel Subarnalata is the sequel of Pratham Pratisruti. The novel was published in Kolkata: Mitra and Ghosh, 1967. The translation bears the same name Subarnalata. All page numbers here are from Gopa Mazumdar, (Tr.), Subarnalata, Chennai: Macmillan, 1997. See, Mazumdar, 1997, 159. For discussions, see, Dipannita Datta 2015, 26.

${ }^{51}$ Subarnalata 1997: 158, 159, 160. Also see Dipannita Datta 2015.
} 
this important lesson. But that is not all'. Women too have to learn their lessons. ${ }^{52}$ If changes were to be brought about, women too needed to make an effort to overcome not only the patriarchal culture that has created a gulf between the sexes but also the complexities of the material/spiritual dichotomy.

As I conclude I would like to point out that all the authors discussed were unable to underestimate the past. And, as they took recourse to the past they assessed the past from the point of view of the current situation and envisioned a non-sectarian future for all. For each of these women writers, literary feminism or creative feminism was a voyage of discovery of the self, of the national self and of all humans accross the planet Earth. In the wide spectrum of responses generated by the British rule in India, their evolving position eventually stood out in its conviction that the colonial situation be used creatively to the long-term benefit of the Indian women and men (and they were not thinking merely of the elites) above and over the historical fact of colonial rule and its injustices. Today, globalism is understood as a similar expression of colonialism. Feminism as an advanced discourse on the uplift of women, as Toril Moi observed, is on the verge of erasure. These authors of an ex-colony and now a third world country could think of a relationship between the personal and the philosophical, and they linked themselves to the political reality of the time. Their feminist approach towards future developments makes us think about equality in a broadened sense and can help the home and the world meet the challenges posed by the forces of globalisation. I suggest that colonial legacy enabled the women of the third world or women of the global south sustain the first world feminist.

\section{References}

Bagchi, J. (ed.) (1995). Indian Women: Myth and Reality. Hyderabad: Sangam Books.

Chatterjee, P. (1997). Our Modernity. Sephis and Codesria: Rotterdam \& Dakar.

-. (1993). The Nation and Its Fragments: Colonial and Postcolonial Histories, Princeton: Princeton University Press.

${ }^{52}$ For a discussion see, Dipannita Datta 2015, 128-130. 
Dipannita Datta: Tradition Transformation and Postcolonial Feminism in India

-. (1989). The Nationalist Resolution of the Women's Question. In Kumkum Sangari and Sudesh Vaid (eds.) Recasting Women: Essays in Colonial History. New Delhi: Kali for Women.

- (1986). Nationalist Thought and the Colonial World: A Derivative Discourse. London: Zed Books.

Chaudhuri, M. (ed.) (2004). Feminism in India. New Delhi: Kali for Women and Women Unlimited.

Chaudhuri, R. (2002). Gentlemen Poets in Colonial Bengal. Calcutta: Seagull.

Chowdhury, I. (Tr.) (2004). The First Promise. New Delhi: Orient Longman.

Dasgupta, S. (1998). Indian Literature, 187 [Sep-Oct], 208-214.

Datta, D. (2015). Ashapurna Devi and Feminist Consciousness in Bengal. New Delhi: Oxford University Press.

- (2012). Nationalism, Anti-Colonialism and Universalism in lmperial India: The Poetry of Toru Dutt. Understanding Britain, Reader 1. London: $32-42$.

-. (2004). Womanhood, a Myth and Reality. South Asian Review, 25, 327-44.

-. (2001). A Caged Freedom, Kolkata: Writers Workshop.

Devi, A. (1995). Indian Women Myth and Reality. In: Jasodhara Bagchi. (ed.), Indian Women: Myth and Reality. Hyderabad: Sangam Books.

- (1967). Subarnalata. Kolkata: Mitra and Ghosh.

-. (1964). Pratham Pratisruti (in Bengali). Kolkata: Mitra and Ghosh.

Dutt, T. (1882). Ancient Ballads and Legends of Hindustan, London: Kegan Paul.

Engels, D. (1983). The Age of Consent Act of 1981: Colonial Ideology in Bengal. South Asia Research, 3, 107-125.

Gandhi, L. (1998). Postcolonialism and Feminism. Postcolonial Theory: A Critical Introduction. New Delhi. Oxford University Press.

Iyengar, K.R. S. (1983). Indian Writing in English. New Delhi: Sterling.

Jayawardena, K. (1986). Feminism and Nationalism in the Third World, London: Zed Books.

Kishwar, M. (2004). A Horror of "Isms": Why I do not Call Myself a Feminist. In Chaudhuri, Maitrayee (ed.), Feminism in India. New Delhi: Kali for Women and Women Unlimited.

—. (1991). Why I Do Not Call Myself a Feminist. Manushi, 63-4, 38-40.

Kumar, R. (1993). The History of Doing: An Illustrated account of Movements for Women's Rights and Feminism in India, 1800- 1990. New Delhi: Zubaan. 
Lewis, R. and Mills, S. (2003). Feminist Postcolonial Theory: A Reader. Routledge: USA and Canada.

Lokuge, C. (2006). Toru Dutt: Collected Prose and Poetry. New Delhi: Oxford University Press, 2006.

Liddle, J and Joshi, R. (1985). Gender and Imperialism in British India. Economic and Political Weekly, 20, WS 72-WS 78.

Mazumdar, G. (Tr.) (1997). Subarnalata. Chennai. Macmillan.

Mazumdar, V. (2001). Whose Past, Whose History, Whose Tradition?: Indigenising Women's Study in India. Asian Journal of Women's Studies (AJWS), 7, 133-53.

Mohanty, C. T. (2003). Third World Women and the Politics of Feminism. Feminism Without Borders: Decolonising Theory Practicing Solidarity. Durham and London: Duke University Press.

Mukherjee, M. (2003). Perishable Empire. New Delhi: Oxford University Press.

Sarkar, T. (2001). Hindu Wife, Hindu Nation: Community, Religion, and Cultural Nationalism, Delhi: Permanent Black.

Sen, A. (2005). Women and Men. The Argumentative Indian, London: Penguin Books.

Tagore, R. (2001). The Oxford Tagore Translations. New Delhi: Oxford University Press.

Walby, S. (1990). Theorising Patriarchy. Oxford, London: Basil Black Well. 